\title{
MAOA Gene
}

National Cancer Institute

\section{Source}

National Cancer Institute. MAOA Gene. NCI Thesaurus. Code C118615.

This gene is involved in the metabolism of neuroactive and vasoactive amines. 